\title{
Soils bioremediation of hydrocarbons and green waste elimination through composting process
}

\author{
Hicham Rhbal ${ }^{1,2,3}$, Salah Souabi ${ }^{1}$, Mohamed Safi ${ }^{1}$, Mohamed Terta ${ }^{4}$, Mohmed Arad ${ }^{3}$, \\ Abdelkader Anouzla ${ }^{1, *}$, Mohamed Hafid ${ }^{4}$ \\ ${ }^{1}$ Laboratory of the Water and of Environment Engineering FSTM University Hassan II, Mohammedia, Maroc \\ ${ }^{2}$ Laboratoire de Virologie et Hygiène \& Microbiologie - FSTM Université Hassan II, Mohammedia, Maroc \\ ${ }^{3}$ Laboratory of Quality Control of Anonym Company of Industry and of Refinery, Mohammedia, Morocco \\ ${ }^{4}$ Laboratoire d'Ecologie et Environnement Département De Biologie Université Cadi Ayyad, Faculté Des Sciences Samlalia
}

\section{Email address:}

aanouzla@gmail.com (A. Anouzla)

\section{To cite this article:}

Hicham Rhbal, Salah Souabi, Mohamed Safi, Mohamed Terta, Mohmed Arad, Abdelkader Anouzla, Mohamed Hafid. Soils Bioremediation of Hydrocarbons and Green Waste Elimination through Composting Process. International Journal of Environmental Monitoring and Analysis. Special Issue: Environmental Science and Treatment Technology. Vol. 2, No. 6-1, 2014, pp. 13-22. doi: 10.11648/j.ijema.s.2014020601.13

\begin{abstract}
The aim of this work was to study the mineralization of hydrocarbons during composting. For this purpose, soil/green waste mixtures were prepared at three different ratios ( $\mathrm{S} / \mathrm{GW}=60 / 40,70 / 30,80 / 20)$ composted for 90 days. An unamended polluted soil (100\% soil) was used as the control. The results indicate that the composting process greatly increased the overall rate of hydrocarbon mineralization. The greatest loss of hydrocarbons was obtained in the first compost with the most green waste $(96 \%)$, followed by the second where losses were still high (78\%). In the compost with the least green waste, the hydrocarbon concentration decreased by only $64 \%$. The hydrocarbon level in the control system remained practically unchanged. In addition, mineralization time increased with increasing green waste ratios, the composting process played a considerable role in the biodegradation of petroleum hydrocarbons and minimized the green waste produced by restaurants and cafeterias. The data obtained will be useful for solid waste management policy making.
\end{abstract}

Keywords: Petroleum Hydrocarbons, Green Waste, Refinery, Composting, Solid Waste Management

\section{Introduction}

Oil pollution accidents are nowadays become a common phenomenon and have caused ecological and social catastrophes [1, 2]. Apart from accidental contamination of ecosystem, the vast amounts of oil sludge's generated in refineries from water oil separation systems and accumulation of waste oily materials in crude oil storage tank's bottoms pose severe problem because many of the standard treatment processes used to decontaminate soil and groundwater have been limited in their application, are prohibitively expensive, or may be only partially effective $[3,4,5]$. Therefore, despite decades of research, successful bioremediation of petroleum hydrocarbon contaminated soil remains a challenge [6]. Bioremediation has been intensively studied over the past two decades, driven by the need for a low-cost, in situ alternative to more expensive engineering-based remediation technologies [7, 8, 9]. Bioremediation has been applied to remove crude oil $[10,11,12$.$] , motor oil [13] and diesel fuel$
[14] from soil, but the removal efficiency is highly variable [15] During bioremediation, the microorganisms were able to remove the pollutants owing to their diverse metabolic capabilities $[16,17,18]$. This was evident from the significant increase in the population of some bacteria as Bacillus. subtilis and P. aeruginosa in soil as compared to control. However, higher growth rate of Pseudomonas strains compared to Bacillus strain might be related to higher breakdown and utilization of petroleum hydrocarbons by former strains [19]. In another context, the problem of environmental pollution due to the increasing accumulation of huge amounts of urban waste has encouraged investigation into the recycling of such materials [20]. The waste can be used as organic amendment for both agricultural purposes and for the rehabilitation of degraded areas [21, 22]. However the direct use of these wastes may cause new problems derived from the presence of heavy metals, pathogenic microorganisms, bad odours or phytotoxic organic compounds [23, 24]. These risks can be minimized by stabilizing the organic matter contained in the 
waste through composting [25, 26, 27]. Generally, composting of soils contaminated with hazardous materials is still an emerging ex situ biotreatment technology [28, 29, 30]. However, interest is increasing and it has been shown to be effective in biodegrading petroleum hydrocarbons [31] at the laboratory and/or field scales. We undertook a feasibility study to gain a better understanding of petroleum hydrocarbon biodegradation during a composting process. In mixtures of green waste and hydrocarbon-contaminated soil, the follow up of hydrocarbons concentration and the maturity factor of composting as well as total kjeldahl nitrogen (TKN), organique carbons ( $\mathrm{OC}), \mathrm{C} / \mathrm{N}$ ratio, $\mathrm{pH}$ value and temperature can characterise the performance of the composting used to treat polluted soil. The objective of this research is to provide a simple method of hydrocarbon mineralization through biological treatment as well as to manage restaurant and cafeteria waste. Considering the lack of scientific data on waste management and the multiple difficulties in their generation, we believe that our work will provide useful new data to strengthen the local government decision-making going to more waste management. All determinations were carried out in triplicate in laboratory-scale, for each experimental treatment was done after during 12 weeks.

\section{Material and Method}

\subsection{Contaminated Soil}

This work is based on a SAMIR's refinery soil that was contaminated by petroleum hydrocarbons. The aging factor that can change significantly the hydrocarbons behavior and evolution of these soil pollutants in time is integrated. The purpose is to gain information on hydrocarbon concentration in the site of interest in order to evaluate the likely correlation between soil physical-chemical properties, the hydrocarbon level, and the meteorological conditions, the impact of these factors on the elimination of these pollutants is to be examined (Figure 1).

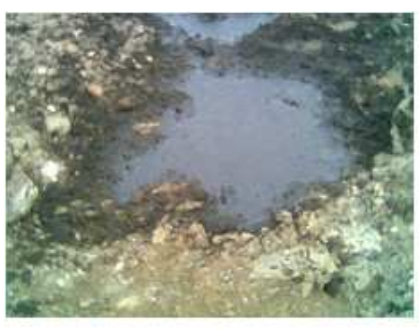

a

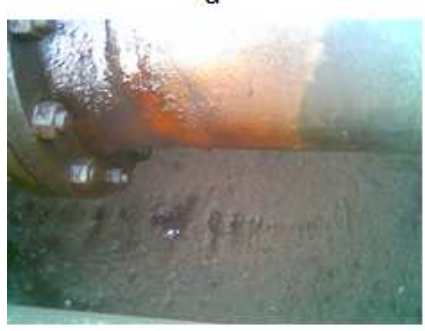

C

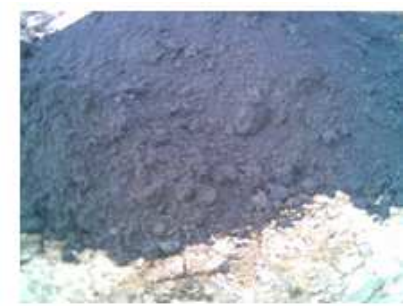

b

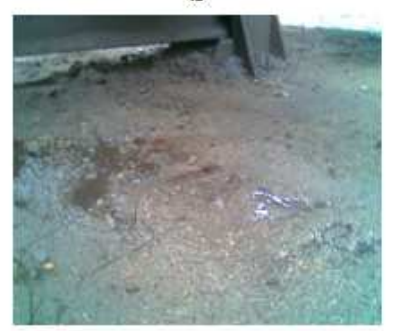

d
Figure 1. Polluted soils in the first $(a, b)$ and second site $(c, d)$
The procedure for soil sampling and preparation was reported by Bivnstingl [32]. Before the present study, the soil was air-dried and homogenised by passing through a $5-\mathrm{mm}$ sieve followed by a 2-mm sieve according to AFNOR norm [33], and stored until treatment. Before experimentation, the soil was diluted by mixing with washed sand (1:1) to provide a more homogeneous distribution of hydrocarbon residues.

\subsection{Green Waste}

The soil was conditioned with an artificial green waste prepared by mixing foodstuff (mixture) of carrots, cucumber, lettuce, onions, potatoes and tomatoes in equal amounts) (3\%dw), sawdust $(38 \% \mathrm{dw})$, leaves $(17 \% \mathrm{dw})$, grass $(27 \% \mathrm{dw})$ and wheat straw $(14 \% d w)$. Foodstuff, sawdust, wheat straw and leaves where separately blended and grass was cut. The composition of the green waste satisfied the nutrient requirement ( $\mathrm{C}: \mathrm{N} 40-50)$ according to the calculations using Cornell's system [34]

\subsection{Amendment}

The soil was conditioned with a Green Waste as amendment agent at three soil/green waste ratios 60/40, 70/30, and 80/20 [35]. As pointed out by [36] of aerobic composting with periodic turning (every 4-5 days) for three months to maintain adequate $\mathrm{O} 2$ levels (Indore System. The Compost moisture content was measured periodically after drying at $105{ }^{\circ} \mathrm{C}$ of defined weight wet soil to ensure that it was maintained at about $60-70 \%$ of the water holding capacity throughout the composting period. The temperature at the surface and in the centre of the compost was monitored daily with a digital temperature probe at 8-10 different sites in the compost. Samples were taken randomly from within the compost and from the outer layer $0,1,2,3 \ldots 12$ weeks after the beginning of the composting process. For analysis, each sample was a mixture of eight subsamples taken from different points in the compost. The samples were homogenized, sieved and air-dried for analysis. The $\mathrm{pH}$ was measured with $\mathrm{pH}$ Crison meter (Micro PH2000) using a soil suspension in water (weight/volume ratio $=2 / 5$ ) according to the [37]. The organic carbon was measured according to the norm [38]. The sample soils passed through a sifter of 315 . The required tests for the determination of the organic carbon varied according to the presumed content of the carbon. The dosage principle was the carbon oxidization of the organic matter by the potassium bichromate in excess, in acidic medium at $135^{\circ} \mathrm{C}$; the remaining bichromate excess was measured by titration with a solution of Mohr salt. This rate in organic carbon allows estimating the rate in organic matter multiplying the result by 2 (Baize, D., 1990). Soil nitrogen content was determined by The Kjeldahl procedure. The method consisted of mineralization by sulphuric acid, followed by a distillation in a basic medium and tittering with sulphuric acid [39].

\subsection{Hydrocarbons Analysis}

Hydrocarbon extraction was performed by shaking-centrifugation, based on the method of [40]. A $1 \mathrm{~g}$ 
sample of dry soil, $2 \mathrm{~g} \mathrm{Na} 2 \mathrm{SO} 4$ and $5 \mathrm{ml}$ dichloromethane were placed in a centrifuge tube, shaken for approximately 45 $\mathrm{s}$ and centrifuged at $4000 \mathrm{~g}$ for $15 \mathrm{~min}$; the supernatant was then decanted into a vial. This procedure was repeated three times. The solvent was evaporated to $2 \mathrm{ml}$ in a rotary evaporator at $740 \mathrm{mbar}$ and $40^{\circ} \mathrm{C}$; the extract was then analyzed by infrared (IR) spectroscopy. TPH concentration was determined by IR spectroscopy using the 8840 EPA modified method with a Nicolet 470 FT-IR spectrophotometer.

\subsection{Bacterial Counts and Isolation}

The total heterotrophic bacterial (THB) count was determined using the spread plate method on nutrient agar (Sigma-Aldrich) according to [41] The samples were collected from each microcosm of treatment. $10 \mathrm{~g}$ of compost was suspended in $100 \mathrm{ml}$ of sodium chloride peptone buffer solution pH 7.2 and mixed thoroughly. The homogeneous suspension was serially diluted with sterile sodium chloride solution. Aliquots of $0.1 \mathrm{ml}$ of 10-1 10-2 10-3 104 10-5 10-6 and 10-7 dilutions were spread on nutritive agar plates in triplicates. All plates were incubated at $37^{\circ} \mathrm{C}$ for $48 \mathrm{~h}$. The number of colony-forming units (CFU) of total bacteria were counted after incubation at $28^{\circ} \mathrm{C}$ for $18 \mathrm{~h}$. Isolated colonies were transferred to nutrient agar and were purified by sub culturing and identified using biochemical tests and microscopy [42].

Identification of Bacteria: after cultures on selective media (King B for Pseudomonas identification, Mcconkey). The bacterial isolates were characterized on the basis of colony morphology, pigmentation, Gram-reaction, cell shape, cell arrangement, relation to oxygen, nutritional and biochemical characteristics according to Bergey's Manual of Determinative Bacteriology [43].

Classification of microorganisms by system API-20E: The organisms were taxonomically identified with the commercial system API-20E. It is a system to Bacterial identification that was done by biochemical analysis according to the standardized micro method [43].

\section{Results and Discussion}

\subsection{Physical and Chemical Parameters of Soil}

The physical chemical parameters of soil used for this study is shown in Table 1

Table 1. Soil chemical properties at the first site

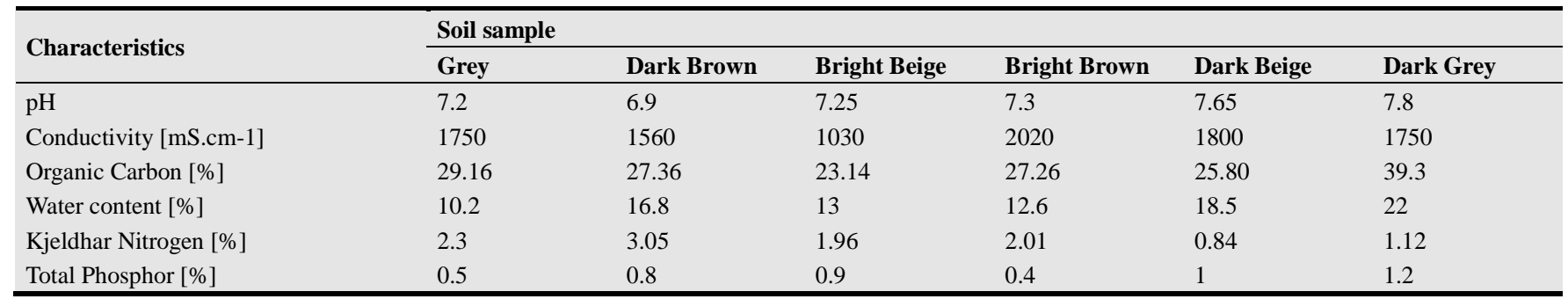

The granulometric analysis shows that sands are the major fraction of both soils, with more than $76 \%$ of the soil, and more than $15 \%$ is loam in the both cases. The experimented soils show that they are very sandy soils according to the textural triangle of grouping studies of the Pedology Problems GEPPA textural triangle [44]; the classification used in the international literature gives the same denominations for the two cases as sandy loam. The chimical analyses indicate that phosphorous in soil is not adequate in comparison to the optimal target 106:10:1. The found values of the $\mathrm{C} / \mathrm{N}$ show that these soils are of agricultural type [45]. The $\mathrm{pH}$ is between 6.9 and 7.8, the $\mathrm{pH}$ of the soils being in limit inferior to the $\mathrm{pH}$ basic fixed by the referential pedological [46]

\subsection{Variation of $\mathrm{pH}$ during Composting of Three Mixtures}

The variation of $\mathrm{pH}$ with the time during composting at different ratios of polluted soil to green waste is shown in Figures 2.

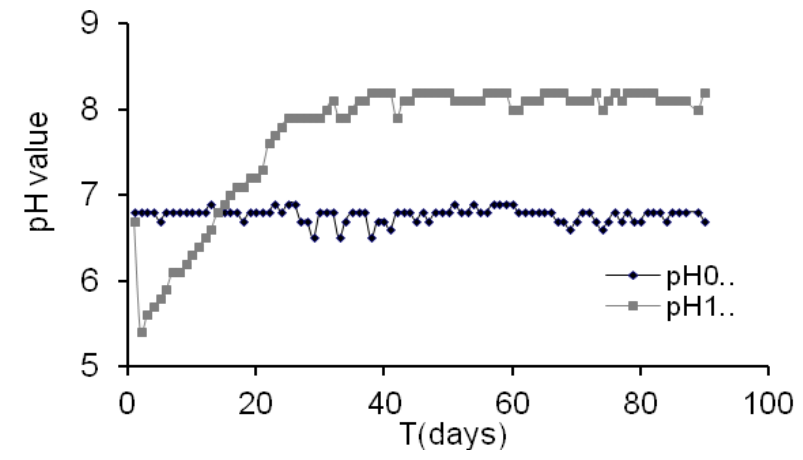

Figure 2a. pH value of the control system (100\% soil) and the first compost (S/GW 60/40) 


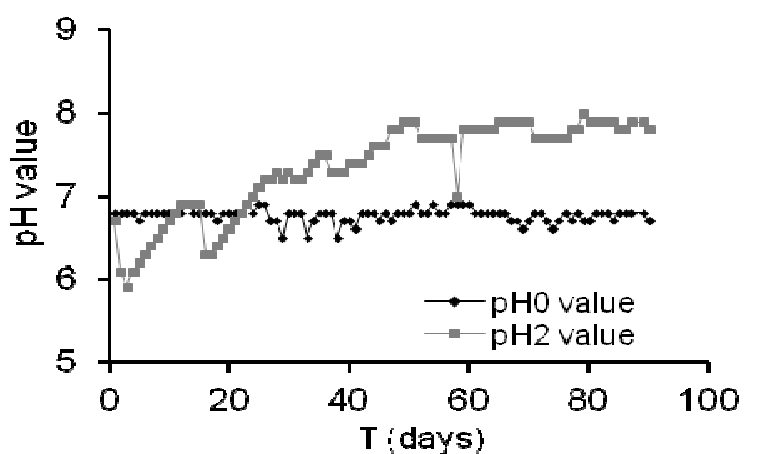

Figure $2 \boldsymbol{b}$. pH value of the control system (100\% soil) and the second compost $(S / G W 70 / 30)$

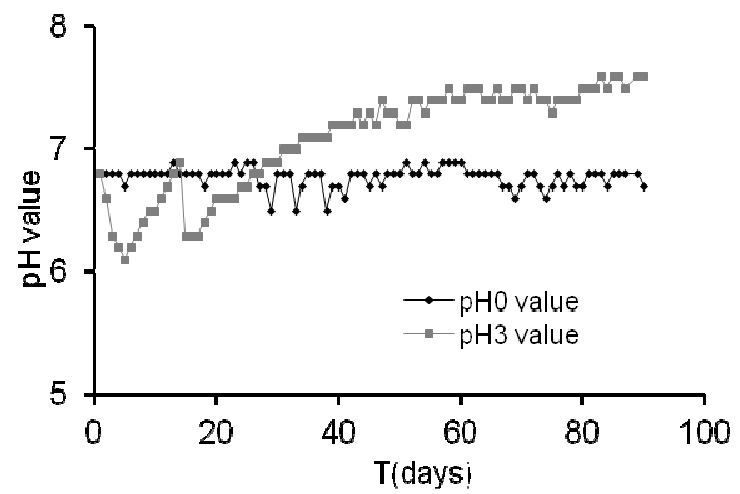

Figure 2c. pH value of the control system (100\% soil) and the first compost $(S / G W 60 / 40$

The $\mathrm{pH}$ value in the first, second and the third compost, reaches its minimum at 5.4, 5.9 and 6.1 respectively, as shown in figure $2 \mathrm{a}, 2 \mathrm{~b}, 2 \mathrm{c}$, the acidification time of the first compost (36h) was shorter than those of the second (48h) and the third compost (120h). The $\mathrm{pH}$ is a function of the accumulated acid production and the decomposition of acids to produce $\mathrm{CO} 2$ and heat [47]. When the rate of acid production is faster than the rate of acid decomposition, acids accumulate so the $\mathrm{pH}$ falls, and when the rates of both acid production and decomposition are equal, the $\mathrm{pH}$ reaches equilibrium. In addition, the compost of higher nitrogen contents had shorter acidification times than those of lower-nitrogen, and the acidification time is determined as the time when the $\mathrm{pH}$ value reaches its minimum. During the composting process, and when the green waste provided necessary nutrient for the bacteria to build cell structures (bacteria growth), most of the carbon and nitrogen in the mixture $(\mathrm{S} / \mathrm{GW})$ were converted into carbon dioxide and ammonia, only a small fraction left in the final product. In composting, ammonia (NH3) is largely emitted when organic matter is actively decomposed [48], then the acids consumed and the ammonia produced are the major factor that controlled the composting process. We noticed at the end of composting process, the $\mathrm{pH}$ value became basic. This shows us the compost maturity indication. In the first and second compost, the mixture with higher and medium green waste ratio $(75 \%)$ and $(50 \%)$ less required time for maturity, the $\mathrm{pH}$ value became basic and reached (8.7) and (7.9) respectively at the end of the composting; the compost with low percentage of green waste $(25 \%)$ provided less nutriments amount. Its $\mathrm{pH}$ value is still basic (7.6) but it requires more time for its maturity.

\subsection{Temperature Evolution during Composting for Different Mixtures}

Temperature is an important factor in the twelve week bioremediation treatment (composting) of contaminated soil. The increase of the compost temperature can be a good indicator of microbial activity. The temperature in the three composts is presented in Figures 3.

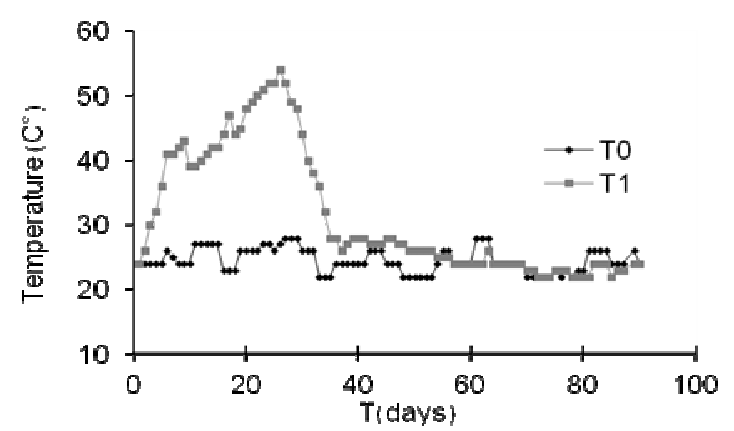

Figure 3.a. Temperature versus time of the control system and the first compost $(40 \%$ green waste and $60 \%$ soil)

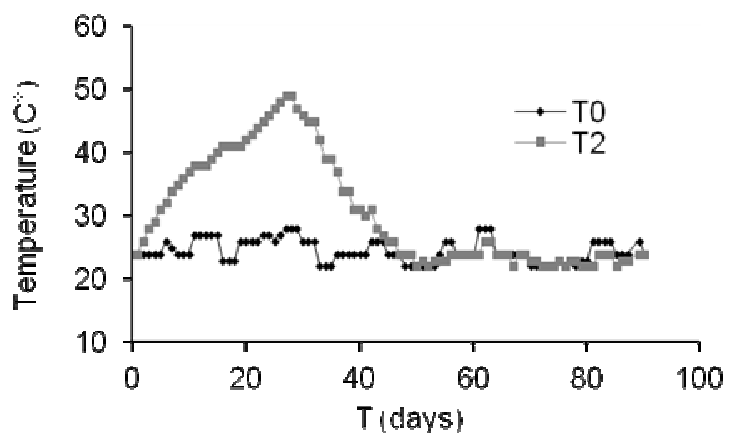

Figure 3.b. Temperature versus time of the control system and the second compost (30\% green waste and $70 \%$ soil)

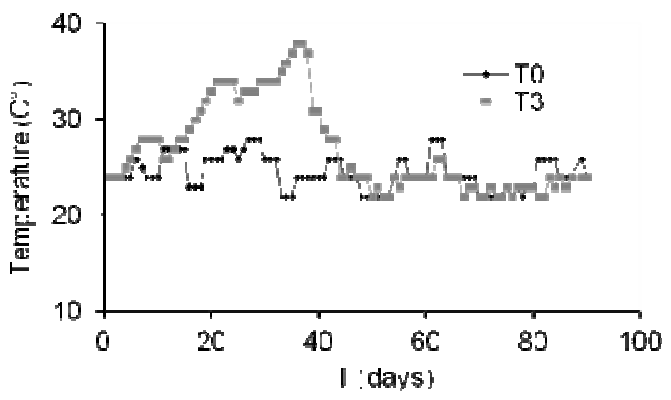

Figure 3.c. Temperature versus time of the control system and the third compost (20\% green waste and $80 \%$ soil)

During the process and for all composts, the temperature increased rapidly and the three typical phases of composting were observed, a short initial mesophilic phase $\left(\mathrm{T}<40^{\circ}\right)$ for approximately two days, a thermophilic phase lasting two weeks, when the temperature increased $\left(\mathrm{T}>40^{\circ}\right)$, a mesophilic and maturation phase after 25-40 days. We observed similar results in all the composts with a difference in the durations of 
the phases and the maximum temperatures $54^{\circ} \mathrm{C}, 49^{\circ} \mathrm{C}$, and $41^{\circ} \mathrm{C}$ for the first, second and the third composts respectively. The thermophilic period indicates higher microbial activity, then compost maturity, shortly after the temperature decreased gradually to the mesophilic stage lasting from days 45-55 of treatment, till it reached the ambient temperature, with no temperature changes occurring during this phase, indicating stabilisation of the compost. It was related to the significant effects of the percentage of green waste. Unamended soil (control system) remained at ambient temperature during the whole period of the process.

Nitrogen evolution during composting for different mixtures

The variation of Total Kjeldahl Nitrogen (TKN) with time for different mixtures of composted waste is shown in figure 4 .

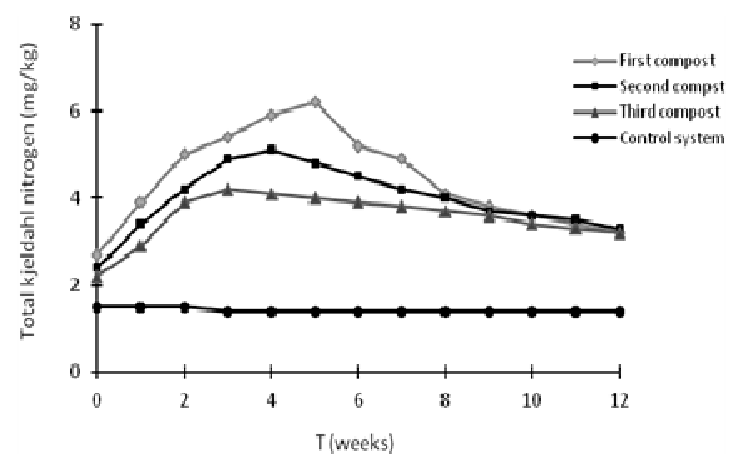

Figure 4. Total kjeldahl nitrogen evolution during the twelve weeks of the treatment

In purpose of the treatment, Two stages were identified in nitrogen evolution (figure 4), in the first stage, three compost provoked an increase in total kjeldahl nitrogen (TKN) in comparison with the control system, it was greater and achieved the maximum $(6.2 \mathrm{mg} / \mathrm{kg})$ in the first compost after five weeks of treatment followed by the second and third compost which obtained $5.1 \mathrm{mg} / \mathrm{kg}$ and $4.2 \mathrm{mg} / \mathrm{kg}$ in sex and four weeks respectively. After this period during the following, the total kjeldahl nitrogen (TKN) content decreased of the first and second compost and it was the third treatment which displayed slightly decreased. However, in control system total kjeldahl nitrogen (TKN) content is unchangeable. Approximately at the end of treatment no difference were detected between the amended soils $(3.2 ; 3.3$ and $3.2 \mathrm{mg} / \mathrm{kg})$.

During the present study green waste was used to approve nitrogen during composting, that's seen in the first stage of treatment, the nitrogen could be used for hydrocarbons mineralization if the waste was applied with composing, the addition of nitrogen can be used to stimulate microbial hydrocarbon degradation $[49,50,51,52,53]$. The nitrogen losses would have been largely due to ammonia volatilization, it was observed in coincidence with the thermophilic stage and hydrocarbons decreasing, a possible explanation may be that it consumed in the composting with hydrocarbons degradation. In fact, ammonia emissions have been proposed in some works as an indicator of the biological activity of composting materials with high nitrogen content [54]. While TPH mineralization is strictly microbial, the impact of nitrogen will be more effective against hydrocarbons biodegradation processes.

\subsection{Total Organic Carbons Evolution during Composting for Different Mixtures}

The Total Organic Carbons evolution with time for different mixtures during composting is shown in figure 5 .

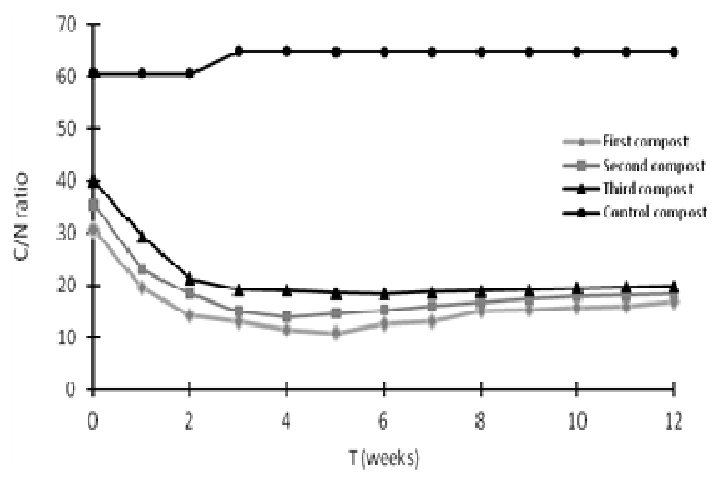

Figure 5. Variation of report $C / N$ ratio for different mixtures during composting

The report $\mathrm{C} / \mathrm{N}$ ratio is an important parameter to index the maturity of compost, which may generally be affected by variations of the compost characteristics; it has a decreasing tendency as the composting process progresses. In our treatment, the $\mathrm{C}: \mathrm{N}$ ratio decreased with time but The difference between the tree compost was significantly different (Table 1). The initial $\mathrm{C} / \mathrm{N}$ ratio of the first and second compost is 30.7 and 35.4 ; it drops gradually to 11.5 and 13.9 on the 30th day and further to 15 and 16.8 on the 60th day respectively. While in third compost the $\mathrm{C} / \mathrm{N}$ ratio decreased from an initial 32.9 to 19 in 30 days of treatment. [57] pointed out that a mature compost $\mathrm{C} / \mathrm{N}$ ratio should be less than 20 After 30 day treatments, the small decrease in the $\mathrm{C} / \mathrm{N}$ ratio in the third compost may also be attributed to compost components, such as low availability of nitrogen resulting from low green waste amount. After this period (30 days), the $\mathrm{C} / \mathrm{N}$ ratio increased in three composts, that was due to the $\mathrm{N}$ losses mainly through ammonia volatilization, the composting of materials with low $\mathrm{C}: \mathrm{N}$ ratio result in more $\mathrm{N}$ losses than in high $\mathrm{C}: \mathrm{N}$ ratio wastes [58,59]. Generally there is decrease in $\mathrm{C}: \mathrm{N}$ ratio after 90 days of treatment, within first second and third compost and reach 16, 16,4 und 18 respectively. To gather information on the quality of the obtained end-product analyses on the hydrocarbon mineralization, results revealed adequate $\mathrm{C} / \mathrm{N}$ values and decreasing of hydrocarbons concentration in treatment. In fact, the compost supplied nutrients for the growth of microorganism which resulted in more microbial activity. Increasing microbial activity may have resulted from adaptation of the microbial ecosystem to the change in temperatures $[60,61,62]$. or to changes in availability nutrient. According to previous information, Compost stability is an important aspect of soil rehabilitation. It relates to the degree to which the hydrocarbons have been eliminated during the composting process. In fact, the hydrocarbons degradation due to losses of carbon mainly as 
carbon dioxide, the carbon content of the compostable material decreased and $\mathrm{N}$ content per unit material increased, which resulted in the decrease of $\mathrm{C}: \mathrm{N}$ ratio. After its, $\mathrm{C} / \mathrm{N}$ ratio is reduced to around 20 by composting, the green waste amounts can then be used for growing hydrocarbons mineralization.

\subsection{Hydrocarbons Removed during Composting of Three Mixtures}

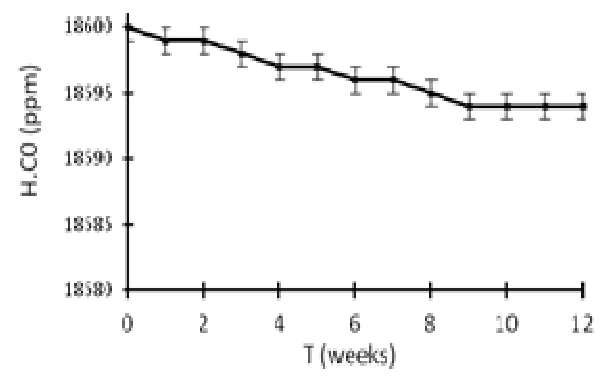

The control system $100 \%$ soil

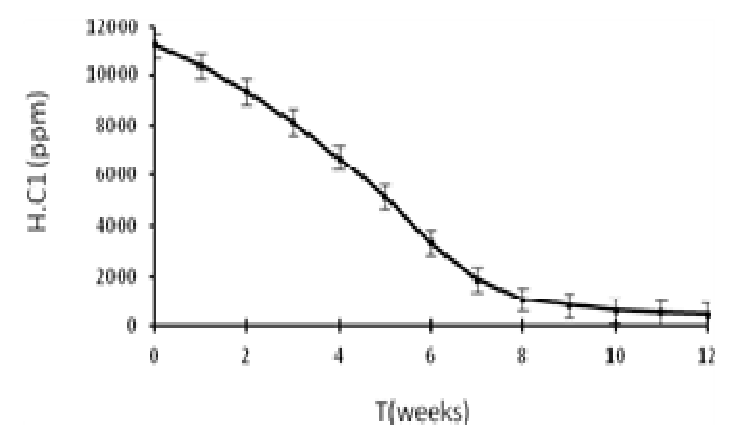

The first compost (GW/S 4/6)

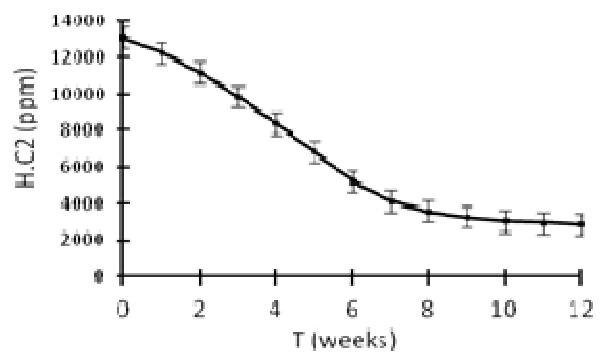

The second compost (GW/S 3/7)

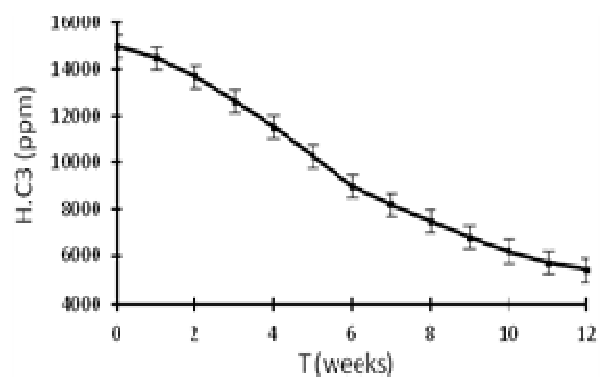

The third compost (GW/S 2/8)

Figure 6. Evolution of the hydrocarbon concentration during composting of three mixtures (Green Waste/Soil: GW/S)
In the control system, where the native soil was unamended by green waste, hydrocarbon removal was insignificant over the whole period of treatment, this was expected since we worked with soil from a dump polluted some time earlier, already influenced by natural phenomena and the hydrocarbons had already undergone a first depletion. The high hydrocarbon concentration shows the presence of persistent hydrocarbons resisting natural phenomena such as weathering, evaporation of the volatile fraction and degradation due to microbial activity, which had no noticeable effect. The removal of hydrocarbons during composting of three mixtures is given in Figure 6. In the first compost, there was a considerable decrease in total hydrocarbons; the level of depletion reached $70 \%$ during the first six weeks and after 12 weeks of treatment, the hydrocarbon concentration had decreased by $96 \%$ from the initial level based on GC-MS analysis results. In the second compost, the losses of hydrocarbon were still high but lower than in the first reaching a $60 \%$ drop after 12 weeks, finally levelling off at $78 \%$. In the third compost, where the contaminated soil was amended with the lowest proportion of green waste $(20 \%$ of total compost), during the first period of treatment (six weeks), hydrocarbon monitoring showed the smallest reduction of their concentration, hydrocarbons depletion reaching $40 \%$, and after the full three months of treatment, depletion reached $64 \%$.

The hydrocarbon level in the control system remained largely unchanged. This gives strong evidence that the presence of nutrient in sufficient quantities during the composting process helps hydrocarbon elimination. Previous investigations [63] have recommended keeping moisture and amendment ratio constant for optimal removal of aged PAHs during composting. Other studies concluded that, addition of food waste provides the nutrients required for enhanced biodegradation of petroleum hydrocarbon $[64,65,66]$. In fact, petroleum hydrocarbons in the soil are degraded more slowly because they are more viscous, less volatile and less bioaviable to microorganisms. On the other hand, the application of green waste to contaminated soil can increase the levels of nutrient and moisture, consequently promoting the dissolution of hydrocarbons in the soil, enhancing their bioavailability. In general, when the compost provides sufficient nitrogen, hydrocarbon mineralization increases, probably due to the microbial increased activity raising the composting temperature. The increase of temperature lowers the viscosity of the petroleum products, thereby increasing oil mobility and hence its interaction with microorganisms. As shown in the experiment, when the composting temperature increased, the trends in hydrocarbon removal were similar for the different composts. Our findings show considerable pollutant depletion during the composting process.

The enumeration of microbial strains

In this present study, the enumeration of microbial populations will provide information concerning the biodegradation potential of the hydrocarbons and/or to test bioremediation efficiency. The bacterial diversity of an experimentally contaminated soil in industrial site was investigated. The compost had the highest bacterial counts and was dominated by the some bacteria throughout this study. 
Some microbial strains able of using hydrocarbon as source of carbon were isolated of wich compost (S/GW 6/4) were recorded from samples, these isolats were purified from samples on the basis of their colony, morphology, biochemical tests and API20E test identification. The isolates identified belonged to genera, Pseudomonas, Bacillus, kelbsiella, serratia, klyvera, Escherichia coli. They were assayed for their hydrocarbon-utilizing potential [67]. It was observed that the pseudomonas played a significant role in petroleum hydrocarbon degradation having shown dominance in the treatment. We showed that the number of colonies was increased while incubate by the compost (S/GW 6/4). Number of colonies increase to 108CFU.ml-1 compared with the control This result showed that the bacteria can grow rapidly on culture containing hydrocarbon compounds rapidly and degrade the hydrocarbon source. Pseudomonas species have a remarkable capacity for the degradation of a broad range of organic pollutants, including $\mathrm{PAH}$, halogenated derivates and recalcitrant organic residues. Pseudomonas putida and Pseudomonas fluorescens, are two examples of well known species capable of PAH degradation frequently reported in PAH-impacted environments [68]. The bacteria belonging to the Bacillus species have these desirable characteristics. They consume organic waste thousands of times faster than the types of bacteria that are naturally present in the waste. They grow and reproduce easily, are non-pathogenic, and do not produce foul odors or gas. Strains of Bacillus subtilis and Pseudomonas aeruginosa isolated from a petroleum contaminated soil sample of North-East India (ONGC oil Weld) grew on a large number of hydrocarbon compounds as a source of carbon and energy demonstrating these strains might be efficient hydrocarbon degraders [69].These strains have been efficient producers of biosurfactants in hydrocarbons rich culture medium. There are reports describing the effect of exogenously added microbial biosurfactants in enhancing the bioremediation of crude oil-polluted soils by indigenous microbes [70].

The various microorganisms have been well studied before and proved to be effective in bioremediation of petroleum polluted soil. Concerning Bacillus. subtilis was proved to be the best to hydrocarbon degrade, and the rates of degradation of diesel oil by the isolate at the end of day one, day twelve and day twenty-seven were $5.8 \times 10 \mathrm{~g} / \mathrm{h}$, respectively. In another study, strains were isolated from petroleum polluted soil and identified as Pseudomonas pseudoalcaligenes, Bacillus firmus, Bacillus alvei, Penicillium funiculosum, Aspergillus sydowii and Rhizopus sp., and they removed 79\%, $80 \%, 68 \%, 86 \%, 81 \%$ and $67 \%$ of TPH. Genus Stenotrophomonas, Bacillus, Brevibacillus, Nocardiodes and Pseudomonas were used in combination and give a degradation rate of $67 \%$ after only 12 days of treatment [71], the Enterobacteriaceae family such as Klebsiella and Serratia genera subject to chronic contamination with domestic sewage from point sources. Nonetheless, the catabolic capacity of Klebsiella strains to degrade hydrocarbons, including PAH, has been previously described. A recent study suggests that this genus could be an important part of the oil-degrading microbial community in estuarine areas exposed to sewage [72].

\section{Conclusion}

This study investigated the effect of adding different ratios of green waste to polluted soils to eliminate hydrocarbons through a composting. We followed hydrocarbon elimination by monitoring hydrocarbon concentration as well as the variation of temperature and $\mathrm{pH}$. These parameters gave a good indication of the success of the composting process in removing oils. We can conclude that temperature and $\mathrm{pH}$ provide valuable information on compost maturity; consequently a good composting process can enable a good proportion of hydrocarbon mineralization. The identified microbial strains of compost that was able of using hydrocarbon as source of carbon and the increasing number of colonies in this microcosm give a good indicator for compost maturity then bioremediation of polluted soil. Bioremediation of polluted soil by adding a green waste amendment and then encouraging a composting process with acceptable chemical properties is a reliable choice, technically feasible, and could be considered as an ecologically viable way to eliminate hydrocarbons from soils. Restaurants and cafeterias located in industrial companies and refineries produce a considerable quantity of green waste and food waste, tons per year, most of this waste is organic with contains nitrogen. It can be used for the remediation of polluted soil. We can conclude that a correlation could occur between the enhancement of contaminant depletion in the soil paralleling the minimization of the quantity of waste produced by restaurants and cafeterias. This observation confirms that composting is a good choice for accelerating the bioremediation of polluted soils while eliminating quantities of organic waste. In terms of implementation and supervision of waste management, establishing composting processes could contribute both to minimizing the disposal of green waste and to restoring good quality to polluted soils. In our opinion, from a technical and economic viewpoint, we recommend the composting process for remediation of polluted soil and elimination of green waste. We believe that our work will provide useful new data to help local municipal decision-making for waste treatment and management.

\section{References}

[1] Burger, A.E., 1993. Estimating the mortality of seabirds following oils pills - effects of spill volume. Mar. Pollut. Bull. 26, 239-248.

[2] Shaw, D.G., 1992. The Exxon-valdez oil-spill-ecology and social consequences. Environ. Conserv. 19, 253-258.

[3] Ferrari, M.D., Neirotti, E., Albornoz, C., Mostazo, M.R., Cozzo, M., 1996. Biotreatment of hydrocarbons from petroleum tank bottom sludge in soil slurries. Biotechnol. Lett. $18,1241-1246$.

[4] Nicholas, R.B., 1987. Biotechnology in hazardous-waste disposal: an unfulWlled promise. Am. Soc. Microbiol. News 53,13 
[5] Vasudevan, N., Rajaram, P., 2001. Bioremediation of oil sludge contaminated soil. Environ. Int. 26, 409-411.

[6] Rahman, K.S.M., Thahira-Rahman, J., Kourkoutas, Y., Petsas, I., Marchant, R., Banat, I.M., 2003. Enhanced bioremediation of n-alkanes in petroleum sludge using bacterial consortium amended with rhamno- lipid and micronutrients. Bioresour. Technol. 90, 159-168.

[7] Merkel, N., Schultez-Kraft, R., Infante, C., 2004. Phytoremediation of petroleum- contaminated soils in the tropics-preselection of plant species from eastern Venezuela. J. Appl. Bot. Food Qual. 78, 185-192.

[8] Chehregani, A., Malayeri, B., 2007. Removal of heavy metals by native accumulator plants. Int. J. Agric. Biol. 9, 462-465.

[9] Chehregani, A., Mohsenzade, F., Vaezi, F., 2009. Introducing a new metal accumulator plant and the evaluation of its ability in removing heavy. Toxicol. Environ. Chem 72, 1349-1353.

[10] Wiltse, C.C., Rooney, W.L., Chen, Z., Schwab, A.P., Banks, M.K., 1998. Greenhouse evaluation of agronomic and crude oil-phytoremediation potential among alfalfa genotypes. J. Environ. Qual. 27, 169-173.

[11] Radwan, S.S., Al-Awadhi, H., Sorkhoh, N.A., El-Nemer, I.M., 1998. Rhizospheric hydrocarbon utilizing microorganisms as potential contributors to phytor- emediation for the oily Kuwait desert. Microbiol. Res. 153, 247-251.

[12] Merkel, N., Schultez-Kraft, R., Infante, C., 2005. Assessment of tropical grasses and legumes for phytoremediation of petroleum-contaminated soils. Water Air Soil Pollut. 165, 235-242.

[13] Dominguez-Rosado, E., Pichtel, J., 2004. Phytoremediation of soil contaminated with used motor oil: II. Greenhouse studies. Environ. Eng. Sci. 21, 169-180.

[14] Chaineau, C.H., More, J.L., Oudot, J., 2000. Biodegradation of fuel oil hydrocarbons in the rhizosphere of maize. J. Environ. Qual. 29, 568-578

[15] Angehrn., D., Ga“ lli, R., Zeyer, J., 1998. Physicochemical characterization of residual mineral oil contaminants in bioremediated soil. Environ. Toxicol. Chem. 17, 268-276.

[16] Sudarat Boonchan, Margaret L. Britz, And Grant A. Stanley 1998. Degradation And Mineralization Of High-Molecular-Weight Polycyclic Aromatic Hydrocarbons By Defined Fungal-Bacterial Cocultures Applied And Environmental Microbiology 64, 4180-4184.

[17] Rachel May Long 2008 The Distribution And Diversity Of Polycyclicaromatic Compound-Degrading Bacteria And Key Degradative Genes Thesis

[18] Priyangshu Manab Sarma, Dhruva Bhattacharya, S. Krishnan, And Banwari Lal 2004 Degradation Of Polycyclic Aromatic Hydrocarbons By A Newly Discovered Enteric Bacterium, Leclercia Adecarboxylata Applied And Environmental Microbiology, 70 3163-3166

[19] Das, K., Mukherjee, A. K., in press. Crude petroleum-oil biodegradation eYciency of Bacillus subtilis and Pseudomonas aeruginosa strains isolated from a petroleum-oil contaminated soil from North-East India. Bioresource Technology 98 (2007) 1339-1345

[20] Kôrner, I., Braukmeier, J., Herrenklage, J., Leikam, K.,
Ritzkowski, M., Schlegelmilch, M., Stegmann, R., 2003. Investigation and optimization of composting processes-test systems and pratical examples. Waste manag. 23, 17-26

[21] Zbytniewski, R., Bszewski, B., 2005a. Characterisation of natural organic matter (NOM) derived from sewage sludge compost. Part 2: multivariate techniques in the study of compost maturation. Biores. Technol. 96, 479-484.

[22] Castaldi, P., Alberti, G., Merella, R., Melis, P., 2005. Study of the organic matter evolution during municipal solid waste composting aimed at identifying suitable parameters for the evolution of compost maturity. Waste Manage. 25, 209-213

[23] Diez, J.A., De la Torre, A.I., Cartagena, M.C., Carballo, M., Vallejo, A., Munoz, M.J., 2001. Evaluation of the application of pig slurry to an experimental crop using agronomic and ecotoxicological approaches. J. Environ. Qual. 30, 2165-2172

[24] Garcia, C., Hernandez, T., Costa, F., 1991. The influence of composting in the fertilizing value of an aerobic sewage sludge. Plant Soil 136, 269-272

[25] Tognetti, S.M., Laos, F., Mazzarino, M.J., Hernandez, M.T., 2005. Compostion vs. Vermicomposting: a comparison of end product quality. Compost Sci. Util. 13, 6-13

[26] Zbytniewski, R., Bszewski, B., 2005b. Characterisation of natural organic matter (NOM) derived from sewage sludge compost. Part 1: chemical and spectroscopic properties. Biores. Technol. 96, 471-478.

[27] Pascual, J.A., Ayuso. M., Garcia, C., Hernandez, T., 1997. Characterization of urban wastes according to fertility and phytotoxicity parameters. Waste Manage. Res. 15, 103-112

[28] Ro KS, Preston KT, Seiden S, bergs MS. Remediation composting process principles: focus on soils contaminated with explosive compounds. Crit Rev Environ Sci Technol 1998;28:253-82

[29] Semple, K.T., Reid, B.J., Fermor, T.R., 2001. Impact of composting strategies on the treatment of soils contaminated with organic pollutants. Environ. Pollut. 112, 269-283.

[30] Antizar-Ladislao B, Lopez-Real JM, Beck AJ. Bioremediation of polycyclic aromatic hydrocarbon (PAH) contaminated waste using composting approaches. Crit Rev Environ Sci Technol 2004;34;249-89

[31] Birnstingl JGA. An investigation into the bioremediation of polycyclic aromatic hydrocarbons in a manufactured gas plan soil. Lancaster (UK): University of Lancaster;1997

[32] Namkoong, W., Hwang, E.-Y., Park, J.-S., Choi, J.-Y., 2002. Bioremediation of diesel-contaminated soil with composting. Environ. Pollut. 119, 23-31.

[33] AFNOR, recueil des normes français, Qualité des sols, AFNOR Edition, (1994), 250 p.

[34] Richard T. Cornell Composting (on line). Available at: compost CSS. Cornell. edu/Composting- homepage. html (accessed 2004), 1995.

[35] Montgomery, D.C., 2003. Diseno y analisis de experimentos, second ed. Wiley Ed S A, CV, Limusa.

[36] Walworth, J.L., Woolard, C.R., Braddok, J.F., Reynolds, C.M., 1997. Enhancement and inhibition of soil petroleum biodegradation through the use of fertilizer nitrogen: an approach to determining optimum levels. J . Soil Contam. 6 (5), 464-480 
[37] French industrial standards authority x 31 - 103 (French industrial standards authority; Quality of soils; 1994)

[38] FRENCH INDUSTRIAL STANDARDS AUTHORITY X 31 109 (French Industrial Standards Authority; Quality of soils), 1994;

[39] Hicham Rhbal, Salah Souabi, Mohamed Safi, Mohamed Arad, Abdelkader Anouzla, 2010.Hydrocarbons diagnostic of polluted soils Chemistry \& Chemical Engineering, Biotechnology, Food Industry, Volume 11, Issue 4, Pages 449-458.

[40] Schwab, A.P., Su, J., Wetzel, S., Pekarek, S., Banks, M.K., 1999. Extraction of petroleum hydrocarbons from soil by mechanical shaking. Environmental Science and Technology 33, 1940-1945.

[41] Chikere, C. B. Okpokwasili1 G. C. and Chikere B. O., 2009 Bacterial diversity in a tropical crude oil-polluted soil undergoing bioremediation, African Journal of Biotechnology Vol. 8 (11), pp. 2535-2540, 3 June, 2009.

[42] Market Abakpa, Enugu State, Nigeria Eze, V.C., Eleke, O.I. and Omeh, Y.S. 2011. Microbiological and nutritional qualities of burukutu sold in mammy. American Journal of Food and Nutrition, 1(3): 141-146

[43] Lakshmipriya V.P. and Sivakumar P.K. 2012. Isolation and Characterization of Total Heterotrophic Bacteria and Exopolysaccharide Produced From Mangrove Ecosystem, International Journal of Pharmaceutical \& Biological Archives 3(3):679-684

[44] Pansu, M, Gautheyrou, J.: L'analyse du sol minéralogique, organique et minérale, Springer, France, Paris, 2003;

[45] INRA: Référentiel Pédologique, Association Française d'Etude de sols, INRA, 1995;

[46] Cerniglia, C.E.: Fungal metabolism of polycyclic aromatic hydrocarbons: past, present and future applications in bioremediation, Journal of Industrial Microbiology and Biotechnology, 1997, 19, 324-333;

[47] Sundberg, C., 2005. Improving compost process efficiency by controlling aeration, temperature and $\mathrm{pH}$. Doctoral thesis, Swedish University of Agricultural Sciences, Uppsala.

[48] Kuroda, K., Hanajima, D., Fukumoto, Y., Suzuki, K., Kawamoto, S., Shima, J., Haga, K., 2004. Isolation of thermophilic ammonium-tolerant bacterium and its application to reduce ammonia emission

[49] Atlas, R.M., 1981. Microbial degradation of petroleum hydrocarbons: an environmental perspective. Microbiol. Rev. 45, 180-209.

[50] Piehler, M.F., Paerl, H.W., 1996. Enhanced biodegradation of diesel fuel through the addition of particulate organic carbon and inorganic nutrients in coastal marine water. Biodegradation 7, 239-247.

[51] Roy, R., Greer, C.W., 2000. Hexadecane mineralization and denitrification in two diesel fuel-contaminated soils. FEMS Microbiol. Ecol. 32, 17-2

[52] Korboulewsky, N., Bonin, G., Massiani, C., 2002. Biological and ecophysiological reaction of white wall rocket (Diplotaxis erucoides L.) grown on biosolid compost. Environ. Pollut. 117, 365-370.
[53] Hutchinson, S.L., Banks, M.K., Schwab, A.P., 2001. Phytoremediation of aged petroleum biosolids: effect of inorganic material. J. Environ. Qual. 30, 395-403.

[54] Liao, P.H., May, A.C., Chieng, S.T., 1995. Monitoring process efficiency of a full-scale in vessel system for composting fisheries wastes. Bioresource Technology 54, 159-163.

[55] Garcia, C., Hernandez, T., Costa, F., Ayuso, M.,1992a. Evaluation of the maturity of municipal waste composts using simple chemical parameters. Comm. Soil Sci. Plant Anal. 23, $1501-1512$

[56] USEPA, 1998a. Method 3051. Microwave Assisted Acid Digestion of Sediments, Biosolids, Soils, and Oils. US Environmental Protection Agency Office of wastewater Management, Washington DC.

[57] Chen, M.J., Liao, C.Z., Tsai, Y.F., 2005. Manual and Case Studies of Composting Technology and Equipment. Issued by the Taiwan Green Productivity Foundation, Prepared for the Industrial Development Bureau, Ministry of Economic Affairs, Taiwan

[58] Reddy, K.R., Kaleel, R., Overcash, M.R., Westerman, P.W., 1979. A nonpoint source model for land areas receiving animal wastes: ammonia volatilization. Trans. ASAE 22, 1398-1405.

[59] Sanchez-Monedero, M.A., Roig, A., Paredes, C., Bernal, M.P., 2001. Nitrogen transformation during organic waste composting by the Rutgers system and its effects on $\mathrm{pH}$, EC and maturity of the composting mixtures. Biores. Technol. 78, $301-30$

[60] Ashbolt, N. J. \& Line, M. A. (1982). A bench-scale system to study the composting of organic wastes. Environmental Quality, $11,405-8$

[61] Nakasaki, K., Shoda, M. \& Kubota, H. (1985b). Effect ot" temperature on composting of sewage sludge. Applied and Environmental Microbiology, 50, 152630.

[62] Sikora, k. J. \& Sowers, M. A. (1983). Factors affecting the composting process. In: Composting $\sim$ fwastes and slurries. (Stentiford, E. (Ed)), Leeds University Press, England, 1-22.

[63] Nakasaki, K., Yaguchi, H., Sasaki, Y., Kubota, H., 1992. Effect of $\mathrm{C} / \mathrm{N}$ ratio on thermophilic composting of garbage. J. Ferment. Bioeng. 73,43,-45

[64] Guerin TF. The differential removal of aged polycyclic aromatic hydrocarbons from soil during bioremediation. Environ Sci Pollut Res 2000; 7:19-26

[65] Joo, H.S., Phae, CG., Ryu, J.Y.,2001. Comparison and analysis on characteristics for recycling of multifarious food waste. J.KOWREC 9, 117-124

[66] Joo, H.S., Shoda, M., Phae, CG., 2007. Degradation of diesel oil in soil using a food waste composting process. Biodegradation 18,597-605

[67] Anene Moneke and Chika Nwangwu 2011 Studies on the bioutilization of some petroleum hydrocarbons by single and mixed cultures of some bacterial species African Journal of Microbiology Research Vol. 5(12), pp. 1457-1466,

[68] Francisco J. R. C. COELHO, Sara SOUSA, Luísa SANTOS, Ana L. SANTOS, Adelaide ALMEIDA, Newton C. M. GOMES and Ângela CUNHA 2010. PAH Degrading Bacteria in an Estuarine System, Interdisciplinary Studies on Environmental Chemistry - Biological Responses to Contaminants, pp. 77-87. 
[69] Das, K., Mukherjee, A.K., 2005. Characterization of biochemical properties and biological activities of biosurfactants produced by Pseudo- monas aeruginosa mucoid and non-mucoid strains isolated from hydrocarbon-contaminated soil samples. Appl. Microbiol. Biotechnol. 69, 192-199.

[70] Abalos, A., Vinas, M., Sabate, J., Manresa, M.A., Solanas, A.M., 2004. Enhanced biodegradation of Casablanca crude oil by a microbial consortium in presence of a rhamnolipid produced by Pseudomonas aeru- ginosa AT 10. Biodegradation $15,249-260$.
[71] Jingchun Tang Xiaowei Niu, Qing Sun, Rugang Wang Bioremediation of Petroleum Polluted Soil by Combination of Ryegrass with Effective Microorganisms , 2010, Journal of Environmental Technology and Engineering 3(2):80-86

[72] Bidoia E. D., R. N. Montagnolli and P. R. M. Lopes, 2010Microbial biodegradation potential of hydrocarbons evaluated by colorimetric technique: a case study current research and education topics in applied microbiology at microbial biotechnology 12771288. 